\title{
セラミックス／金属接合材の破面解析と き裂進展の評価
}

$\begin{array}{lll}\text { 荒 居 善 雄* 土田栄一郎* } & \text { 土宮 垣 淳 二** } \\ \text { 吉 野 元 基** Mark J.Meisner*** }\end{array}$

\section{A Fractographic Study of Crack Growth near Ceramic/Metal Interface}

by

\author{
Yoshio Arai ${ }^{*}$, Eiichiro Tsuchida ${ }^{*}$, Junji Mryagaki ${ }^{* *}$ \\ Motoki Yoshino** and Mark J. Meisner ${ }^{* * *}$
}

\begin{abstract}
Four point bending tests on $\mathrm{Si}_{3} \mathrm{~N}_{4} / \mathrm{SUS} 304$ joints after thermal cycling were conducted and their fracture surfaces were examined by a fractographic method. Based on these results, the fracture path and the criterion for unstable fracture are discussed by a interface fracture mechanics approach. A crack initiates in the ceramic side very close to the ceramic/brazing filler interface; the unstable fracture occurs when $K_{1}$ of the subinterface crack reaches $K_{\mathrm{IC}}$ for the ceramic material. Consequently, strength degradation during thermal cycling is caused by micro-cracking.
\end{abstract}

Key words : Fractography, Ceramic/metal joint, Interface mechanics, Residual stress, Deflection angle, Crack extension

\section{1 緒言}

近年, 性質の異なる部材を接合した材料を機械構造用 材料として用いることが非常に多くなっている．特に， セラミックスの耐熱性, 耐摩耗性などの金属材料にない 長所を活かし，低じん性などの短所を補ったセラミック ス/金属接合材が注目されており，これに関する研究，開 発が多方面で行われている.

従来，フラクトグラフィの手法を用いたセラミックス/ 金属接合材の破壊機構の研究が行われている.1), 2) しか し，「界面破壊」と称される破壊経路を詳細に検討した 報告はないようである。

そこで, 本研究ではさまざまな温度の熱サイクルを受 けたセラミックス/金属接合材を, 4 点曲げ試験によっ て破断し，炎のセラミックス/金属接合材の破面観察を 通して, 接合界面の 3 次元的な破壊経路を検討した。

\section{2 応力拡大係数の評価方法}

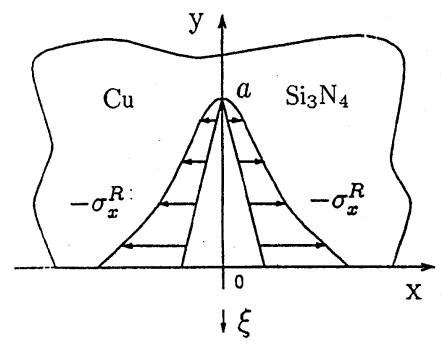

Fig. 1. Interface edge crack and residual stresses.
Hutchinson らに従って，Fig. 1 に示すような座標系で 2 次元界面端き裂の複素応力拡大係数 $K$ を定義する.

き裂先端近傍 $y-a \rightarrow 0$ における応力場は次式で表さ れる.

$$
\begin{gathered}
\sigma_{x}-i \tau_{x y}=\frac{K(y-a)^{i \varepsilon}}{\sqrt{2 \pi(y-a)}}, \quad x=0 \\
K=K_{1}+i K_{2}
\end{gathered}
$$

ここで, $a$ は界面端き裂長さ, $i$ は虚数単位, $\varepsilon$ は接 合された二つの材料の弾性係数から定まる異材定数 である。

Rice らによるき裂面負荷を受ける半無限界面き裂の 解析結果を利用して, 残留応力場の複素応力拡大係数 $K^{R}\left(=K_{1}^{R}+i K_{2}^{R}\right)$ は， $\sigma_{x}^{R}(\xi)$ を初期垂直残留応力場， $\tau_{x}^{R}(\xi)$ を初期せん断残留応力場, $m_{2}$ を半無限き裂の補 正係数, $m_{3}$ を端き裂の補正係数とすると, 重ね合わせ の原理に基づき次式のように求められる.

$$
\begin{aligned}
K_{1}^{R}= & \frac{m_{3}}{m_{2}} \sqrt{\frac{2}{\pi}} \cosh (\pi \varepsilon) \int_{0}^{a} \frac{1}{\sqrt{\xi}}\left[\sigma_{x}^{R}(\xi) \cos (\varepsilon \ln \xi)\right] \\
& \left.-\tau_{x y}^{R}(\xi) \sin (\varepsilon \ln \xi)\right] d \xi \\
K_{2}^{R}= & \frac{m_{3}}{m_{2}} \sqrt{\frac{2}{\pi}} \cosh (\pi \varepsilon) \int_{0}^{a} \frac{1}{\sqrt{\xi}}\left[-\tau_{x y}^{R}(\xi) \cos (\varepsilon \ln \xi)\right] \\
& \left.-\sigma_{x}^{R}(\xi) \sin (\varepsilon \ln \xi)\right] d \xi
\end{aligned}
$$

また，Rice らによる無限遠方で一様引張荷重 $\sigma$ を受 ける無限板中の長さ $2 a$ の界面き裂の解析結果を利用す ると, 複素応力拡大係数 $K^{L}\left(=K_{1}^{L}+i K_{2}^{L}\right)$ は次式で与え られる.

* 正 会 員 埼玉大学工学部機械工学科 7338 浦和市下大久保, Dept. of Mech. Eng., Saitama Univ., Shimo-okubo, Urawa, 338

** 埼玉大学大学院理工学研究科 †338 浦和市下大久保, Graduate Student, Saitama Univ., Shimo-okubo, Urawa, 338

*** Institute for Mechanics and Materials, Univ. of California, San Diego. 


$$
\left.\begin{array}{l}
K_{1}^{L}=m_{3} \sigma \sqrt{\pi a}[\cos (\varepsilon \ln a)+2 \varepsilon \sin (\varepsilon \ln a)] \\
K_{2}^{L}=m_{3} \sigma \sqrt{\pi a}[2 \varepsilon \cos (\varepsilon \ln a)-\sin (\varepsilon \ln a)]
\end{array}\right\}
$$

残留応力と外力考慮した全応力应大係数 $K$ を, 次 式のように重ね合わせで表す。

$$
K=K^{R}+K^{L}
$$

以上の応力拡大係数と窒化ケイ素の破墁じん性值を用 い，窒化尔イ素内几不安定破塙する場合の外応力とき裂 長さの関係を検討した。

なお，中間層の塑性変形がき裂先端近傍セラミックス 側の応力場に及ぼす影響は未知であり，本研究では考虑 していない。

\section{$3 \cdot 1$ 供試材および試験片形状 \\ 3 実 験 方 法}

本研究で用いた供試材は, 接合時に生じる残留応力を 緩和するために中間層として軟質の金属である $\mathrm{Cu}$ を用 いたセラミックス/金属接合材を用いた。接合は活性金 属法で行われ，セラミックスには常压焼結窒化ケイ素 （東芝製 TSN03），金属にはステンレス鋼（SUS304）を 用いた。

各材料の材料特性を Table I, 接合条件を Table II, 試験片形状および寸法を Fig. 2 に示す。

\section{$3 \cdot 2$ 試験方法}

㙓尘イクル試験の試験条件をTablelliに示す。

$T_{\max }$ が $573 \mathrm{~K}, 773 \mathrm{~K}$ の場合の昇温時間は艺れぞれ約 $30 \mathrm{~min}, 60 \mathrm{~min}$ である。なお，冷却は真空中の場合は炉 冷，大気中の場合は空泠によった。

強度試験は，原則として JIS-R-1601「ファインセラミ ックスの曲げ強度試験法」により，荷重方法は 4 点曲げ で, 試験片の接合部が内スパンのほぼ中央に来るように した。ひずみゲージは引張面側のセラミックス，金属部

Table I. Material properties.

\begin{tabular}{|c|c|c|c|}
\hline & $\mathrm{Si}_{3} \mathrm{~N}_{4}$ & $\mathrm{Cu}$ & $\mathrm{SUS} 304$ \\
\hline $\mathrm{E}(\mathrm{GPa})$ & 304 & 108 & 196 \\
\hline$\nu$ & 0.27 & 0.33 & 0.30 \\
\hline$\alpha\left(\times 10^{-6} \mathrm{~K}^{-1}\right)$ & 3.0 & 17.7 & 15.0 \\
\hline
\end{tabular}

Table II. Condition of joint.

\begin{tabular}{|c||c|}
\hline Brazing filler & Ti-Ag-Cu \\
\hline Temperature & $1073 \sim 1123[\mathrm{~K}]$ \\
\hline Atmosphere & Vacuum $1.333 \times 10^{-3} \mathrm{~Pa}$ \\
\hline Interlayer & $\mathrm{Cu}($ thickness $0.2 \mathrm{~mm})$ \\
\hline
\end{tabular}

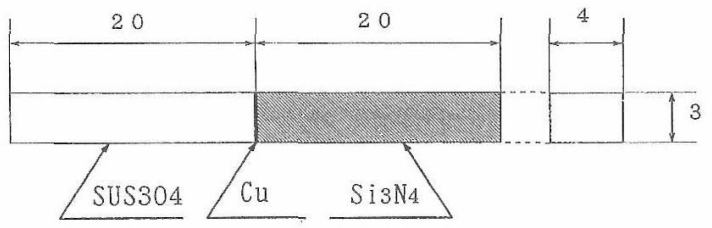

Fig. 2. Specimen configuration(unit:mm).

Table III. Thermal cycle condition.

\begin{tabular}{|c||c|}
\hline Temperature max & $573,673,773,1073[\mathrm{~K}]$ \\
\hline Atmosphere & Air, Vacuum \\
\hline
\end{tabular}

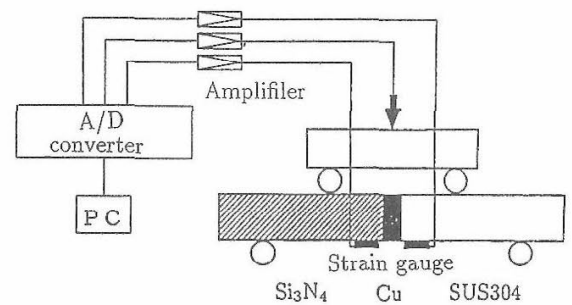

Fig. 3. Monotonic fracture test system.

それぞれの界面近傍に張り付けた。試験条件は室温大気 中で,クロスヘッドスピードは $0.5 \mathrm{~mm} / \mathrm{min}$ で一定とし， 試験片が不安定破壊するまで行った。強度試験方法の実 験系統図をFig. 3 に示す。

\section{3 破面解析方法}

試験片の破断面就よび，試験前の試験片の側面に就い て走査型電子顕微鏡（日立製作所：S-2400）孛用いて破 面観察打よび X 線成分分析を行った。破断面の破面観 察については，通常の垂直方向からの観察と，特にセラ ミックスへの不安定破壊部分の屈折角度算出のために走 查型電子顕微鏡内で試験片を $10^{\circ}$, 扔よび $20^{\circ}$ に傾けた破 面観察を行った。

破壤起点の界面き裂長さは以下の手順で決定した。

(1) 垂直方向からの観察による巨視的破面写真 $(60$ 倍）の不安定破壞部分のき裂進展の流れ具合 (Fig. 4 の 知印）で，破壇起点と考光られる界面き裂群を Fracture origin とする。そして，その界面き裂群を拡大観察した SEM 写真から不安定破壇の屈折点を決める。先の際, 界面からセラミックス内部へ測った屈折点の厚さをh する (Fig. 5)。

（2）（1）であげた候補の中で，界面からのセラミック ス内への屈折角度 $\theta$ を以下の方法で求め，先の值が相刘 的に緩やかな箇所を破壞起点の界面き裂と判断した (Fig. 6).

・き裂の属折地点を SEM 写真上で判定してそこをX

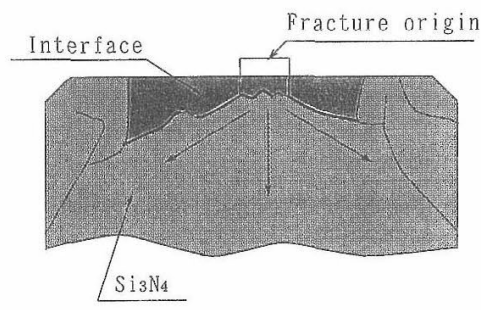

Fig. 4. Determination of Fracture origin.

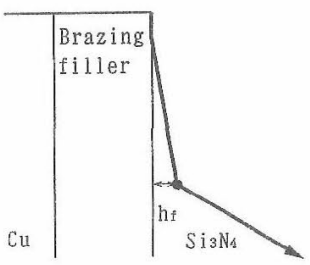

Fig. 5. Definition of $h_{f}$. 

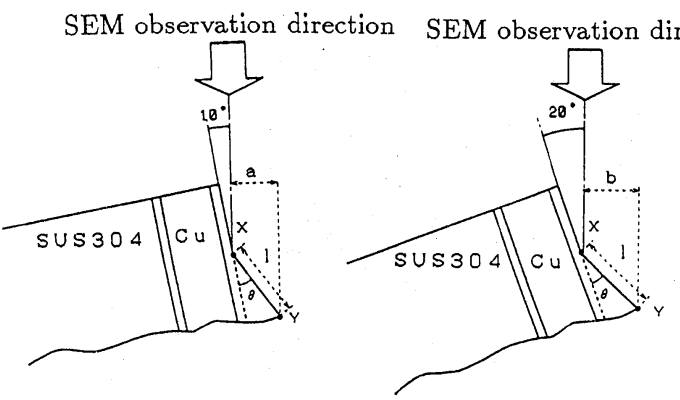

Fig. 6. Configuration of height measurement.

点と決め, $\mathrm{X}$ 点から $20 \mu \mathrm{m}$ 程度の距離（Fig. 6の 1 ) にY 地点を定める. $20 \mu \mathrm{m}$ 程度の距離としたのは, 簡単のために直線近似を行うためである。

- X 点を中心として $10^{\circ}$, 打よび $20^{\circ}$ 傾けた破面の写 真上で XY 地点間に相当する部分の長さをそれぞれ $a, b$ とすると, 求める屈折角度 $\theta$ は次式で表さ れる.

$$
\theta=\tan ^{-1}\left[\frac{\frac{a}{b} \sin 20^{\circ}-\sin 10^{\circ}}{\cos 10^{\circ}-\frac{a}{b} \sin 20^{\circ}}\right]
$$

（3）（2）で確定できない場合は, 従来通り，その中で 界面き裂長さが相対的に短いところを破壊起点の界面き 裂と判断した.

\section{$4 \cdot 1$ 強度試験結果}

\section{4 実 験 結 果}

4 点曲げ試験により破断した各試験片のうち, 破壊起 点が試験片幅方向中央部 (以下貫通き裂と称する, 試験 片 30 本中 14 本）となった試験片の試験条件, 曲け強度 とともに, 後述する界面き裂長さ, 不安定破壊時の屈折 角度，および前述の屈折点の厚さ $h_{f}$ を Table IV および Fig. 7 に示す.

巨視的破面写真（60 倍）の観察によれば，界面き裂 長さはき裂前縁に沿って変動している。，そこで, Fig. 7 の界面き裂長さについては, その変動を幅で示し, 前述 した破壊起点に打ける界面き裂長さをプロット点で示し ている. また, Fig. 7 の破線は外応力のみを考慮した場 合, 実線は残留応力と外応力を考虑した場合の, $K_{1}=$

TableIN. Interface crack length and deflection angle.

\begin{tabular}{||c||c|c|c|c|c|}
\hline $\begin{array}{c}\text { Specimen } \\
\text { number }\end{array}$ & $\begin{array}{c}\text { Crack } \\
\text { length } \\
{[\mu \mathrm{m}]}\end{array}$ & $\begin{array}{c}\text { Bending } \\
\text { strength } \\
{[\mathrm{MPa}]}\end{array}$ & $\begin{array}{c}\text { Deflect. } \\
\text { angle } \\
{[\mathrm{deg} .]}\end{array}$ & $\begin{array}{c}\mathrm{h}_{\mathrm{f}} \\
{[\mu \mathrm{m}]}\end{array}$ & $\mathrm{T}_{\max }$ \\
{$[\mathrm{K}]$}
\end{tabular}

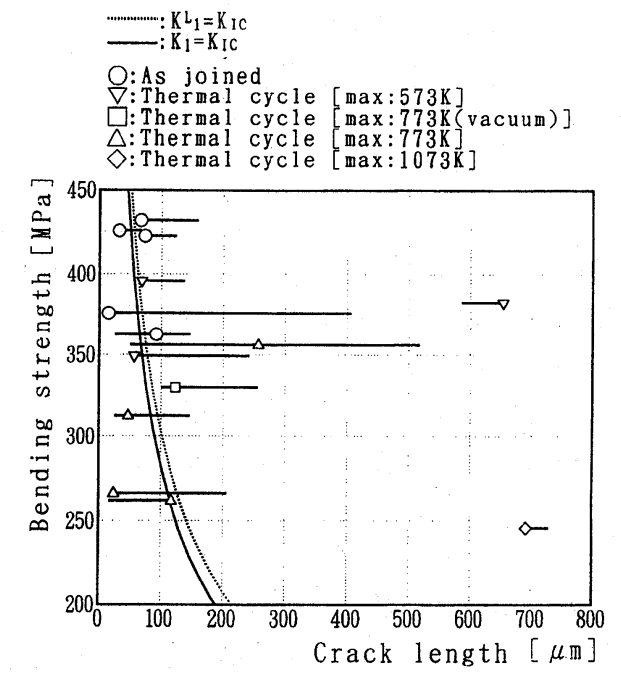

Fig. 7. Relation between bending strength and crack length.

$K_{I C}\left(\mathrm{Si}_{3} \mathrm{~N}_{4}\right)$ における曲げ応力とき裂長さの関係を示して 打り,このことから, 3.3 節の方法によって破壊起点の 界面き裂を決定すれば，多少のばらつきはみられるもの の，ほほ $K_{1}=K_{\mathrm{I} C}$ でセラミックス内への不安定破壊が起 こっていると考えられる.

\section{$4 \cdot 2$ 破面解析結果}

以下に, 代表的な試験片の SUS304 側の巨視的破面 写真と SEM 写真を示す. 写真はすべて上側が引張面で ある。

$\mathbf{4} \cdot \mathbf{2} \cdot 1$ 熱サイクルを受けない場合 N15 試験片の 倍率 60 倍の巨視的写真 (Fig. 8) は, 比較的理想的な 貫通き裂の破面である。破壞起点は試験片上側（4 点曲 げ試験の引張側）であり，界面き裂は，引張面ほぼ中央 から下側へ放射状にき裂が進展したと考えられ， Fracture origin として Fig. 8 中に示した試験片中央付近 が破壊起点の界面き裂と考えられる。

Fracture origin 部を倍率 300 倍で拡大した SEM 像 (Fig. 9) で観察すると，不安定破壊部分の屈折角度が他 に比べ緩やかで，ほぼ同じ角度の中央の $\mathrm{A} ， \mathrm{~B}$ 二つの界 面き裂が破壊起点の候補と考えられる。

しかし，この部分を $20^{\circ}$ 傾けた倍率 400 倍の SEM 像 （Fig. 10）で観察すると, 界面き裂 $\mathrm{A} の$ 不安定破壞部分 が, 界面端部から約 $200 \mu \mathrm{m}$ の地点で界面き裂 $\mathrm{B}$ の不安 定破壊部分を吸収して合体し，光の背後まで滑らかにつ ながっていることがわかる。したがって，界面き裂 $\mathrm{A} を$ 破壊起点の界面き裂と判断することができる.

なお, X 線成分分析結果から界面き裂は, セラミック スとろう材の界面のわずかにセラミックス側で発生して おり, Fig. 8 の Fracture origin 部を $20^{\circ}$ 傾けて倍率 800 倍に拡大した SEM 写真 Fig. 11 を観察すると, 界面近傍 にはく離や割れなどはほとんど見られずその意味でほぼ 平滑であった。

また, 倍率 8000 倍で破壊起点部金属側の SEM 像 （Fig. 12）の観察を行ったところ，いわゆる「界面き裂 部」にセラミックス単体で破壊した場合に得られる破面 


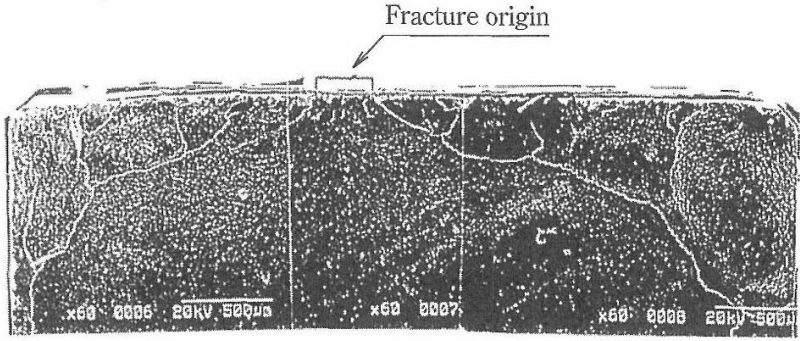

Fig. 8. N15 SEM photography.

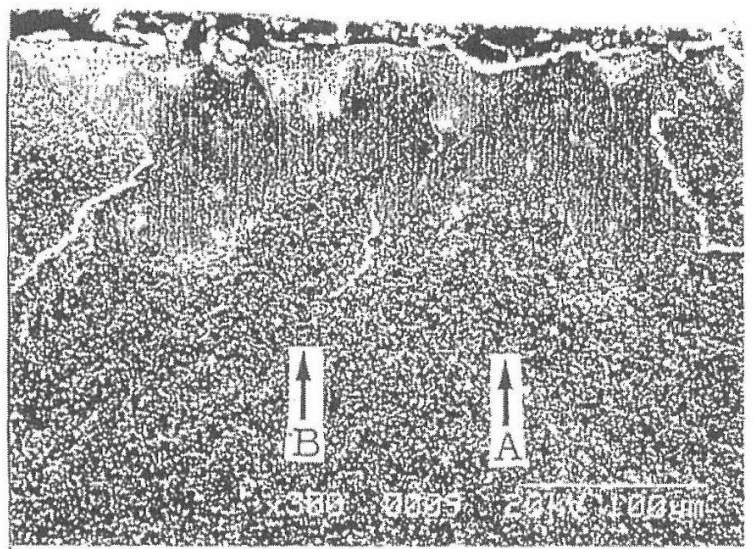

Fig. 9. N15 Detail of fracture origin $\left(\mathrm{N} 15,0^{\circ}\right)$.

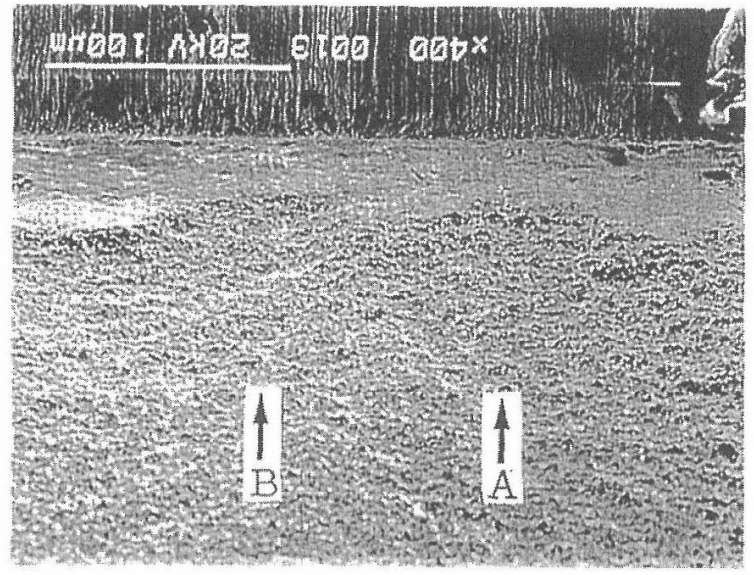

Fig. 10. Inclined image of fracture origin $\left(\mathrm{N} 15,20^{\circ}\right)$.

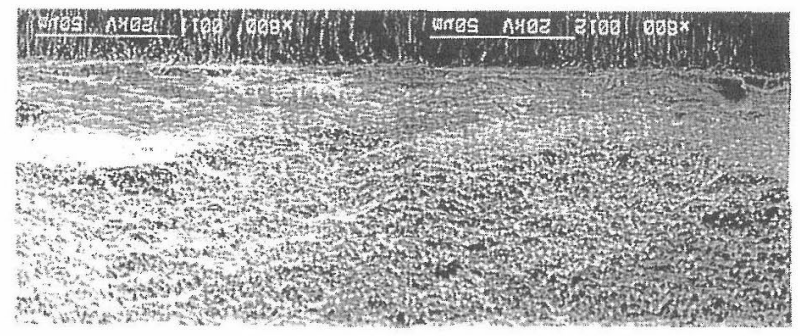

Fig. 11. Inclined image fracture origin (N15, $20^{\circ}$ high magnification).

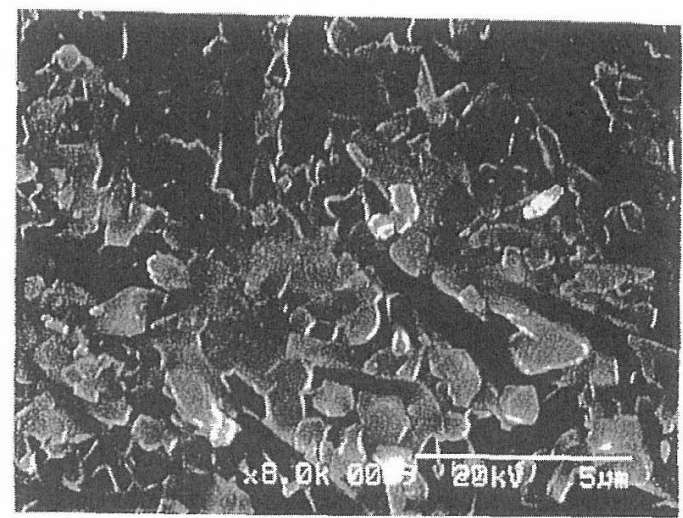

Fig. 12. N15 SEM photography.

と同様な窒化ケイ素特有の柱状組織が見られ，き裂の進 展は，セラミックスの粒界抢よび粒内を同じような割合 で進展しているが，ボイド等の大きな塑性変形は観察さ れなかった。

なお，一般的に倍率 60 倍程度の巨視的破面写真の不 安定破壞の部分のうち, 黒く見兑ている部分は不安定破 壞部の属折角度が相効的に小さく，白く見えている当部分 は大きくなる。

$4 \cdot 2 \cdot 2$ 熱サイクルを受けた場合 大気中で熱サイ クル $773 \mathrm{~K}$ の熱サイクルを受けた M 24 試験片の倍率 60 倍の巨視的破面写真（Fig. 13）は，全体的に不規則な 割れ方である。

き裂進展の方向を確定するのは困難で专るが，20傾 けた倍率 600 倍の SEM 像（Fig. 14）に見られるよう に，巨視的破面写真の中央右寄りの界面き裂 $\mathrm{C}$ の不安 定破壊部分は，只の背後と連続的にはなっていないこと 等から, Fracture origin として Fig. 13 中に示した引張面 の左側付近から下側全体へのき裂進展の流机に注目でき， この付近が破壞起点の界面き裂と考党られる。

そこで, Fig. 13 の Fracture origin 部を $20^{\circ}$ 傾けた倍率 150 倍の SEM 像（Fig. 15）で観察す当と，不安定破壊 屈折角度が緩やかな界面き裂 $\mathrm{A}, \mathrm{B}$ が破壞起点と考元ら れる。

しかし，Fig. 13 の Fracture origin 部を $20^{\circ}$ 傾けて倍率 800 倍に拡大した SEM 写真 Fig. 16 学観察すると, 界面 き裂 B はほとんど界面の露出がなく，破壊起点とは考光 にくい状態である。したがって，界面き裂 $\mathrm{A}$ を破壞起点 の界面き裂と判断した。

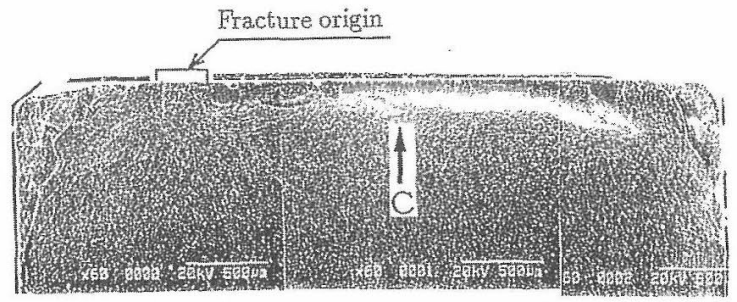

Fig. 13. M24 SEM photography. 


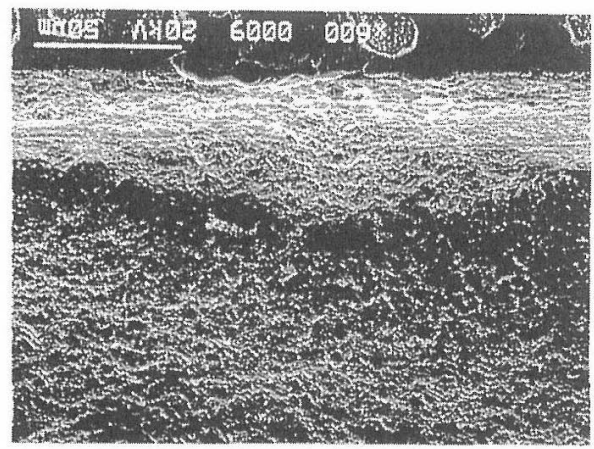

Fig. 14. Inclined image of region C (M24, 20 $)$.

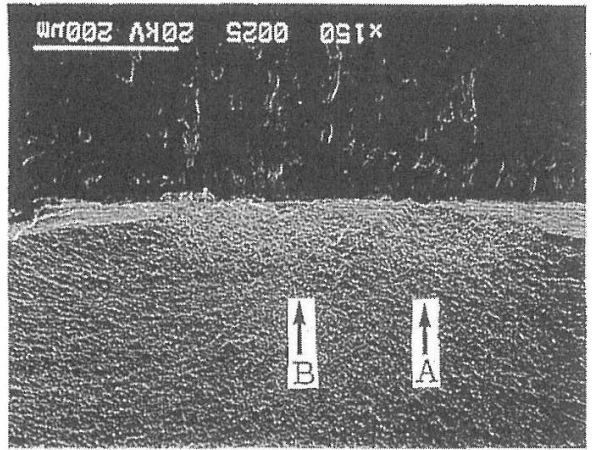

Fig. 15. Inclined image of fracture origin (M24, 20 ).

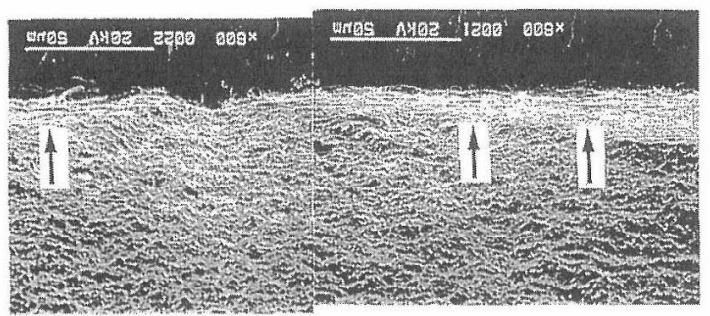

Fig. 16. Inclined image around microcracks $\left(\mathrm{M} 24,20^{\circ}\right)$.

なお，この試験片ではFig.160矢印に示す様に熱サイ クルをかけた試験片の特徴の一つである試験片のセラミ ックスとろう材の界面付近に多くの界面はく離がはっき りと観察できる。

\section{5 考察}

（1）本研究で用いたセラミックス/金属接合材の場合， 界面き裂はうう材/セラミックスの界面のごく近傍のセラ ミッタス側に抢いて発生し，界面にほぼ平行に進展した 後，セラミックス側へ大きく屈折して不安定破壊に至る と考えられる。一例としてN15 の成分分析結果を Fig. 17 に示し，SEM 観察から得られるき裂進展経路を Fig. 18 に示す。なお，Fig. 17 は3.3節の方法によって決定し た破壞起点の界面き裂長さを Crack length $a$ として示 し，その界面き裂，拉よび只の延長線上の代表的な点に おりる $\mathrm{Si}, \mathrm{Ag}, \mathrm{Cu}$ のカウント数を示している。また， この点はFig. 18 にも刘応している。なお，Fig. 18 は横方 向尺度と不安定破䏅時の屈折角度を 5 倍で示してある。

（2）本研究で決定した界面き裂長さと曲げ強度の関係 はFig. 7 から, 界面き裂の応力搪大係数の実部 $K_{1}$ がセラ

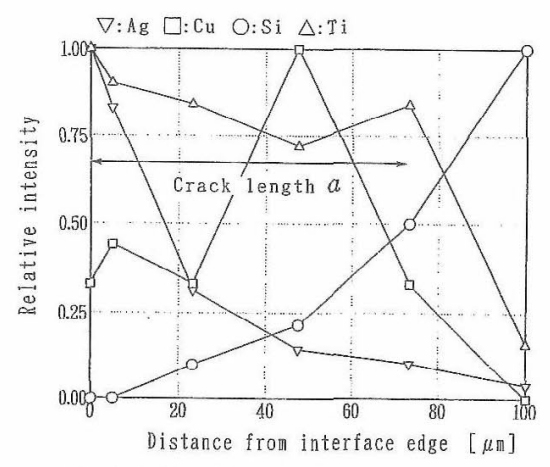

Fig. 17. Result of compositional analysis.

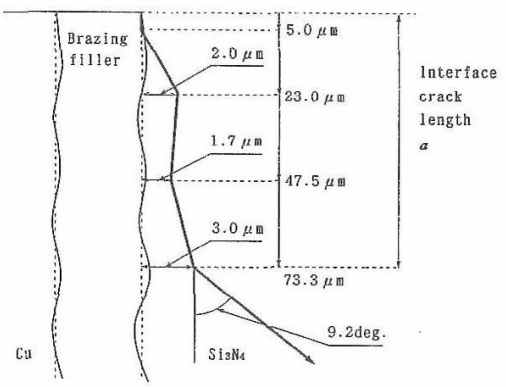

Fig. 18. Crack path in cross section.

ミックスの破壊じん性值 $K_{\mathrm{IC}}$ に羍して破壊する場合の界 面き裂長さと曲げ強度の関係に合致している。多少のば らつきが見られるのは, 界面き裂の形状の複雑さが原因 だと考えられる。また，界面き裂が発生した界面端部か らセラミックス側への屈折地点までは, 熱サイクルの有 無やその最高温度に関係なく，傾き角が $0.06^{\circ} \sim 1.36^{\circ}$ 程 度とほぼフラットな破面となっていた。また，不安定破 壊時のセラミックス内への屈折角度と, 試験片の熱サイ クルの有無，曲げ強度との関係は認められなかった。

(3) Fig. 7 から，熱サイクルを受けた試験片は熱サイ クルを受けていない試験片に比べ曲げ強度が低くなって いる。また，熱サイクルを受けた試験片の山でも熱サイ クル最高温度の高い方が曲げ強度が低い。コーナーき裂 となった試験片でも同様な傾向があるが，この理由とし ては，Fig. 16 に見られるように熱サイクルによってセラ ミックスとろう材の界面部分に微小な久俩が発生するた め, 低応力でそれらが合体し, 不安定破壊基準 $\left(K_{1}=\right.$ $K_{\text {IC }}$ ）に達する為と考えられる。また，不安定破壊時にき 裂がセラミックス側へ屈折することの力学的解釈は今後 の課題であるが，中間層とろう材の弾塑性変形の効果な ビが考えられる。

\section{参考文 献}

1）小林英男, 荒居善雄，長島伸夫，材料，40，689（1991）。

2) 浅見克敏, 新開 毅, 田中俊一郎, 材料, 38, 490 (1989).

3) J. W. Hutchinson, M. E. Mear and J. R. Rice, Trans. ASME, J. Appl. Mech., 54, 828 (1987).

4) 荒居善雄, 土田栄一郎, 内藤政克，小林英男，日本機械 学会論文集, A-61，1473（1995）。 